\title{
MENUMBUHKAN RASA SENANG BERHITUNG DENGAN METODE JARIMATIKA PADA PESERTA DIDIK TK
}

\author{
Choirul Kurniawan \\ Pendidikan Matematika IKIP Budi Utomo Malang \\ choirulkurniawan58@gmail.com
}

\begin{abstract}
Abstrak
Penelitian ini bertujuan untuk mengukur dan menumbuhkan rasa senang dalam menghitung dengan metode jarimatika. Penelitian ini merupakan penelitian tindakan kelas. Teknik untuk pengumpulan data terdiri dari lembar observasi, wawancara dan dokumentasi. Teknik analisis dengan menggunakan variabel yang sudah dibuat meliputi aspek keaktifan di kelas dan bagaimana cara peserta didik menggunakan jarinya saat pembelajaran berlangsung. Berdasarkan penelitian yang telah dilakukan diketahui bahwa pembelajaran jarimatika dapat membantu peserta didik menumbuhkan rasa senang dalam belajar matematika dan hasilnya peserta didik mampu menggunakan jarinya untuk menghitung. Metode menggunakan jari memang sangat mudah dilakukan peserta didik khususnya seusia TK, apalagi didukung dengan trik berhitung dengan menggunakan jari sangat disukai anak.
\end{abstract}

Kata kunci: menumbuhkan, rasa senang, metode, jarimatika

\begin{abstract}
This study aims to measure and foster a sense of pleasure in counting with the jarimatika method. This research is a classroom action research. Techniques for data collection consist of observation sheets, interviews and documentation. Analysis techniques using variables that have been made include aspects of activeness in the classroom and how students use their fingers when learning takes place. Based on research that has been done, it is known that jarimatika learning can help students foster a sense of pleasure in learning mathematics and as a result students are able to use their fingers to count. The method of using fingers is very easy for students to do especially in kindergarten age, moreover it is supported by counting tricks by using fingers which are very preferred by children.
\end{abstract}

Keywords: cultivate, pleasure, method, jarimatika

\section{PENDAHULUAN}

Undang-undang tentang Pendidikan Nasional yaitu Nomor 20 Tahun 2003 yang telah berlaku saat ini menyatakan bahwa jalur pendidikan formal untuk pendidikan anak usia dini dapat berbentuk Taman Kanak-Kanak, 
Raudhatul Athfal, atau bentuk lainnya yang sederajat. Pelajaran Matematika disampaikan di semua sekolah, termasuk pada anak usia dini. Tujuan dari pembelajaran matematika menurut Permendiknas nomor 22 tahun 2006 adalah melatih cara berpikir, bernalar dan menarik kesimpulan, mengembangkan kreativitas, kemampuan pemecahan masalah dan menyampaikan informasi dan gagasan.

Penyampaiaan materi perlu diatur klasifikasi kelas agar peserta didik merasa nyaman dan tujuan belajar bisa tercapai. Karena hal tersebut, maka TK Bahrul Ulum Desa Karangduren Kecamatan Pakisaji Kabupaten Malang membagi tiap angkatan dengan perbandingan guru dengan peserta didik adalah 1:10. Peserta didik dituntut untuk segera menghafal angka pada jarinya sebagaimana rumus jaritmatika ketika di kelas. Perkalian dan pembagian dianggap susah tetapi guru maupun orang tua dirumah dapat mengemasnya dengan cara yang menyenangkan.

Pada perkembangannya saat ini memang banyak metode yang digunakan dalam pembelajaran matematika, misalkan metode jarimatika. Jarimatika merupakan cara berhitung dengan menggunakan jari-jari tangan yang mudah dan menyenangkan (Wulandari, 2008). Metode menggunakan jari memang sangat mudah dilakukan peserta didik khususnya seusia TK, apalagi didukung dengan trik berhitung dengan menggunakan jari sangat disukai anak. Tentunya jika peserta didik senang dengan metode ini, apalagi tanpa terasa mereka juga seakan bermain maka ilmu pengetahuan khususnya matematika akan mudah diterima.

Penelitian sebelumnya pernah dilakukan oleh Pramita (2017) mengenai pelatihan berhitung dengan jarimatika, Sitio (2017) tentang penerapan jarimatika untuk meningkatkan hasil belajar, Septiyawili (2016) mengenai penggunaan jarimatika dalam meningkatkan kecepatan berhitung, Asih (2009) tentang penerapan jarimatika dalam meningkatkan pemahaman konsep terkait penjumlahan dan pengurangan, Sumiati (2018) mengenai efektifitas pembelajaran dengan menggunakan jarimatika terhadap ketuntasan belajar peserta didik, Utami (2018) tentang pengaruh jarimatika terhadap hasil belajar, Nurani (2014) mengenai perancangan buku jarimatika, dan Sumirat (2016) tentang pengaruh praktik jarimatika terhadap keterampilan berhitung perkalian. Berdasarkan penelitian-penelitian tersebut, belum ada yang meneliti tentang penerapan metode jarimatika untuk menumbuhkan rasa senang berhitung pada anak.

\section{METODE PENELITIAN}

Penelitian ini merupakan penelitian tindakan kelas (PTK). Guru dan peneliti berkolaborasi untuk mengenalkan dan mempraktekkan pengoperasian jari bagi peserta didik di kelas. Tujuan dari penelitian ini adalah untuk 
mendeskripsikan bagaimana penggunaan cara berhitung jarimatika dapat menumbuhkan rasa senang pada peserta didik TK. Data yang diambil menggunakan data jenis kualitatif yakni berupa deskripsi berdasarkan hasil observasi dan wawancara.

Pelaksanaan penelitian dilaksanakan dalam empat tahap. (1) Tahap perencanaan, yaitu perencanaan dengan menggunakan teknik jarimatika. (2) Tahap Tindakan, yaitu pelaksanaan tindakan dengan teknik jarimatika dalam proses pembelajaran matematika TK Bahrul Ulum Desa Karangduren Kecamatan Pakisaji Kabupaten Malang. (3) Tahap Pengamatan/Observasi, yaitu pengamatan terhadap pelaksanaan penggunaan teknik jarimatika pada peserta didik di kelas. (4) Tahap Evaluasi, pada tahap ini data didapatkan dari proses pembelajaran di kelas, dan diukur dengan capaiaan pembelajaran, serta dievaluasi.

Subjek dari penelitian ini adalah peserta didik kelas A TK Bahrul Ulum Desa Karangduren Kecamatan Pakisaji Kabupaten Malang. Subjek penelitian adalah 20 peserta didik. Sedangkan objek dari penelitian ini adalah kegiatan pembelajaran berhitung di kelas A TK Bahrul Ulum Desa Karangduren Kecamatan Pakisaji Kabupaten Malang dengan jaritmatika.

Teknik pengumpulan data dalam penelitian meliputi wawancara, observasi, dan tes. Arikunto (2001: 30) berpendapat bahwa wawancara adalah suatu cara yang digunakan untuk mendapatkan jawaban dari responden. Wawancara dilakukan kepada guru maupun peserta didik kelas A TK Bahrul Ulum Desa Karangduren Kecamatan Pakisaji Kabupaten Malang tentang materi yang diajarkan dan kesulitan yang dialami peserta didik dalam menyelesaikan soal perkalian dan mengenai efektifitas penggunaan teknik jarimatika. Observasi dilakukan pada tahap pelaksanaan tindakan kelas dan mengukur keberhasilan tindakan dalam menumbuhkan rasa senang berhitung melalui metode jarimatika.

\section{HASIL DAN PEMBAHASAN}

Sebelum melaksanakan penelitian, survei awal dilakukan dengan tujuan untuk mengetahui keadaan sebenarnya di lapangan. Berdasarkan hasil wawancara dengan guru dan peserta didik kelas A TK Bahrul Ulum Desa Karangduren Kecamatan Pakisaji Kabupaten Malang, banyak peserta didik yang mengalami kesulitan mempelajari Matematika. Berdasarkan wawancara yang dilakukan diketahui bahwa guru belum menggunakan metode pembelajaran yang dapat menumbuhkan rasa senang peserta didik terhadap materi matematika. Penelitian dilakukan dalam dua siklus yang dirangkum pada tahaptahap berikut ini. 
Pada tahap perencanaan, peneliti mengadakan observasi terhadap proses pembelajaran matematika di kelas A untuk mengetahui media, metode, dan strategi yang sesuai. Selanjutnya peneliti bersama guru menyiapkan silabus, Rencana Pelaksanaan Pembelajaran (RPP), lembar tes evaluasi, alat peraga dan lembar observasi.

Pada tahap pelaksanaan tindakan, peneliti melaksanakan pembelajaran dengan menggunakan teknik jarimatika sesuai dengan RPP yang telah disusun. Pada pertemuan pertama peneliti dan guru membuka kegiatan kelas dengan berdoa dan memberikan pengarahan tentang metode jarimatika pada pelajaran matematika. Pada pertemuan kedua peneliti dan guru menyampaikan bagaimana cara menghitung dengan jarimatika tentang menghitung $2+2,3+3$, $4+4$, dan seterusnya. Pada pertemuan ketiga peneliti dan guru membagi kelompok dan mempratekkan penggunaan jarimatika mempresentasikan di depan kelas. Kegiatan menghitung ini dilakukan secara bergantian dengan meningkatkan jumlah hitungan jika dianggap peserta didik mengerti dengan metode ini. Selain itu peneliti dan guru memberikan tugas di rumah, dan guru menutup kegiatan pembelajaran hari itu.

Tahap observasi adalah tahap dimana peneliti dan guru melakukan observasi proses pembelajaran. Adapun hasil observasi bagi peserta didik adalah kemauan peserta didik dalam memperhatikan penjelasan guru masih kurang, peserta didik kurang aktif menjawab pertanyaan guru bahkan masih ada yang mengobrol dengan teman lain di luar materi pelajaran, peserta didik sudah memiliki rasa ingin tahu yang tinggi, keberanian peserta didik maju dalam melakukan kegiatan unjuk kerja masih rendah, serta keberanian menyatakan pendapat dan mengajukan pertanyaan masih kurang.

Berdasarkan hasil observasi peneliti menemukan hasil sebagai berikut: guru kurang inovasi dalam mengajar, kurangnya memberikan motivasi pada peserta didik, khususnya saat pembelajaran berlangsung, guru memberikan aturan di kelas kurang tegas, dan guru kurang memberikan kesempatan kepada peserta didik untuk merumuskan kesimpulan. Dengan demikian dapat disimpulkan bahwa penelitian dalam siklus I belum menunjukkan keberhasilan dalam proses pembelajaran.

Berdasarkan refleksi tersebut, maka peneliti mencari solusi untuk diterapkan di siklus II. Tindakan pada siklus II yaitu pemberian motivasi yang lebih kepada peserta didik serta memberikan arahan dengan lebih detail tentang langkah-langkah yang digunakan dalam pembelajaran menggunakan teknik jarimatika. Pada saat pembelajaran peneliti meminta peserta didik maju secara acak dalam mendemonstrasikan formasi jarimatika dan menghitung perkalian dengan menggunakan teknik jarimatika. Hasil observasi pada siklus II menunjukkan bahwa antusias peserta didik meningkat dalam pembelajaran di kelas, keaktifan peserta didik ditunjang dengan peneliti dan guru menarik 
dalam penyampaiaan, dan keingintahuan peserta didik tinggi karena peneliti dan guru memberikan stimulus.

Berdasarkan hasil penelitian disimpulkan bahwa perserta didik sangat antusias dalam pembelajaran di kelas. Metode menggunakan jari memang sangat mudah dilakukan peserta didik khususnya seusia TK, apalagi didukung dengan trik berhitung dengan menggunakan jari sangat disukai anak. Diharapkan ke depan guru kelas lebih inovasi dalam memberikan dan menyampaikan khususnya mata pelajaran matematika. Berdasarkan penelitian yang telah dilaksanakan, metode jarimatika dapat menumbuhkan rasa senang peserta didik. Hal ini sesuai pendapat Wulandari (2008) yang menyatakan bahwa jarimatika merupakan cara berhitung dengan menggunakan jari-jari tangan yang mudah dilakukan dan menyenangkan.

\section{KESIMPULAN DAN SARAN}

Berdasarkan penelitian yang telah dilaksanakan dengan menerapkan metode jarimatika pada peserta didik kelas A TK Bahrul Ulum Desa Karangduren Kecamatan Pakisaji Kabupaten Malang dapat disimpulkan bahwa pembelajaran dapt menumbuhkan rasa senang belajar berhitung peserta didik kelas A semester 1 TK Bahrul Ulum Desa Karangduren Kecamatan Pakisaji Kabupaten Malang.

Saran yang dapat diberikan yaitu sebaiknya guru TK menerapkan pembelajaran yang menyenangkan kepada peserta didik untuk belajar matematika dengan menggunakan jari-jarinya untuk menghitung, salah satunya dengan metode jarimatika yang mana ini bisa dilakukan untuk penjumlahan dan perkalian dengan menyesuaikan silabus untuk usia TK. Penelitian selanjutnya juga dapat dilakukan untuk mengetahui secara lebih mendalam bagaimana keefektivan metode jarimatika dalam meningkatkan pemahaman konsep berhitung peserta didik.

\section{DAFTAR RUJUKAN}

Arikunto, Suharsimi. (2001). Dasar-Dasar Evaluasi Pembelajaran. Bandung: PT Remaja Rosdakarya

Asih, Ni Made. (2009). Penerapan Metode Jarimatika untuk Meningkatkan Pemahaman Konsep Penjumlahan dan Pengurangan pada Peserta didik Kelas 1 dan 2 SDN 6 Sesetan Denpasar Selatan. Jurnal Pendidikan dan Pembelajaran, 16(1), 1-8.

Kementerian Pendidikan Nasional. (2006). Permendiknas Nomor 22 Tahun 2006 Tentang Standar Isi untuk Satuan Pendidikan Dasar dan Menengah. Jakarta: Kementerian Pendidikan Nasional.

Nurani, Ainin dan Nugrahardi R. (2014). Perancangan Buku Interaktif Jarimatika Penjumlahan dan Pengurangan sebagai Alternatif Pembelajaran 
Matematika untk Anak Usia 5-7 Tahun. Jurnal Sains dan Seni Pomits, 3(1), 13-17.

Pramita, Dewi. (2017). Pengenalan dan Pelatihan Berhitung dengan Jarimatika dan Sempoa di SDN 10 Ampenan. Jurnal Masyarakat Mandiri, 1(1), 46-51.

Septiyawili, Beny Yonas. (2016). Penggunaan Metode Jarimatika dalam Meningkatkan Kecepatan Berhitung Perkalian Bilangan 6 Sampai 10 untuk Peserta Didik SD Kelas 3 di SD Blunyahan 1 Bantul Yogyakarta. Skripsi. Program Studi Teknologi Pendidikan Universitas Negeri Yogyakarta.

Sitio, Tiarmina. (2017). Penerapan Metode Jarimatika untuk Meningkatkan Hasil Belajar Matematika Peserta didik Kelas 1 SDN 003 Pagaran Tapah Darussalam Kabupaten Rokan Hulu. Jurnal Primary Program Studi Pendidikan Guru Sekolah Dasar Fakultas Keguruan dan Ilmu Pendidikan Universitas Riau, 6(1), 146-156.

Sumiati. (2018). Efektifitas Pembelajaran Matematika pada Perkalian Melalui Metode Jarimatika terhadap Ketuntasan Belajar Kelas 1 SDN Sindanwangi 1 Tahun 2016. Jurnal Elementaria Edukasia, 1(1), 58-65.

Sumirat, I., Trimurtini, dan Wahyuningsih. (2016). Pengaruh Praktik Jarimatika terhadap Keterampilan Berhitung Perkalian pada Peserta didik Kekas II SD. Jurnal Kreatif, 4(6), 63-72.

Undang-Undang Republik Indonesia. (2003). Undang-undang Republik Indonesia tentang Sistem Pendidikan Nasional Nomor 20 Tahun 2003. Jakarta: Undang-Undang Republik Indonesia.

Utami, Nur Aini Tri. (2018). Pengaruh Metode Jarimatika terhadap Hasil Belajar Perkalian Peserta Didik Kelas II SD Negeri Gadingan dan SD Negeri Punukan Kulon Progo. Skripsi. Program Studi Pendidikan Guru Sekolah Dasar Universitas Negeri Yogyakarta.

Wulandari, Septi Peni. (2008). Jarimatika Perkalian dan Pembagian. Tangerang: PT Kawan Pustaka. 